ISSN : 0825-8643

\title{
Organizational Redesign, Information Technologies and Workplace Productivity
}

Benoit DOSTIE

Rajshri JAYARAMAN

\section{Cahier de recherche $n^{\circ}$ IEA-08-06}

July 2008

Copyright (C) 2008 HEC Montréal.

Tous droits réservés pour tous pays. Toute traduction ou toute reproduction sous quelque forme que ce soit est interdite. Les textes publiés dans la série des Cahiers de recherche HEC n'engagent que la responsabilité de leurs auteurs.

La publication de ce Cahier de recherche a été rendue possible grâce à des subventions d'aide à la publication et à la diffusion de la recherche provenant des fonds de l'École des HEC.

Direction de la recherche, HEC Montréal, 3000, chemin de la Côte-Sainte-Catherine, Montréal (Québec) Canada H3T 2 A7. 
Institut d'économie appliquée

HEC Montréal

3000 chemin de la Côte-Sainte-Catherine

Montréal (Québec) H3T 2A7

Canada

http://www.hec.ca/iea

iea.info@hec.ca

Copyright (c) 2008 HEC Montréal.

Tous droits réservés pour tous pays. Toute traduction ou toute reproduction sous quelque forme que ce soit est interdite sans l'autorisation expresse de HEC Montréal.

Les textes publiés dans la série des Cahiers de recherche HEC Montréal n'engagent que la responsabilité de leurs auteurs.

ISSN : 0825-8643 


\title{
Organizational Redesign, Information
}

\section{Technologies and Workplace Productivity*}

\author{
Benoit Dostie ${ }^{\dagger}$ and Rajshri Jayaraman ${ }^{\ddagger}$
}

July 17, 2008

\begin{abstract}
Using a large longitudinal, nationally representative workplace-level dataset, we explore the productivity gains associated with computer use and organizational redesign. The empirical strategy involves the estimation of a production function, augmented to account for technology use and organizational design, correcting for unobserved heterogeneity. We find large returns associated with computer use. We also find that computer use and organizational redesign may be complements or substitutes in production, and that the productivity gains associated with organizational redesign are industry-specific. JEL classification: D20, L20, M54, O33
\end{abstract}

\footnotetext{
${ }^{*}$ We gratefully acknowledge comments from seminar participants in Berlin, Munich, Verona, Vienna, Bayreuth, and Valencia, as well as financial support from the Social Sciences and Humanities Research Council of Canada through the Initiatives on the New Economy program and HEC Montréal.

${ }^{\dagger}$ Corresponding author, Institute of Applied Economics, HEC Montréal, University of Montréal, Montréal (Québec), H3T 2A7 ; IZA, CIRANO, CIRPÉE and CREF; benoit.dostie@hec.ca

‡European School of Management and Technology (ESMT), Berlin jayaraman@esmt.org
} 


\section{Introduction}

After a 2 decade lull, productivity in the U.S. and Canada picked up considerably between 1995-2000. In the U.S., for example, business sector labor productivity grew at an average annual rate of $2.6 \%$ from 1996-2000 compared to $1.5 \%$ from 1987-1995. Analogous figures for Canada over the same periods were $2.2 \%$ and $1.0 \%$, respectively. ${ }^{1}$ Using a growth accounting exercise, Jorgensen and Stiroh (2000) and Oliner and Sichel (2000) argued prominently that this could be attributed to increased investment in information technologies (IT), which led to a direct increase in the productivity of the IT sector and a larger indirect increase in productivity in those industries which invested (most heavily) in IT.

The productivity explosion in the first 5 years of the millenium has largely vindicated this view (Jorgensen, Ho, and Stiroh (2006)). However, there are at least two reasons to believe that IT cannot be the full story. First, the sustained productivity growth in the first 5 years of this century has been accompanied by a collapse in IT investment. Second, there is evidence to suggest that the returns to IT are larger than one would expect using a standard growth accounting framework, which typically only takes into account tangible assets (Brynjolfsson and Yang (2001).)

Brynjolfsson and Hitt (2003) maintain that a missing piece in this productivity puzzle is complementary investments in organizational design accompanying computerization. This is an idea which is gaining currency in policy circles. ${ }^{2}$

The basic argument of Brynjolfsson and co-authors is that firms are not going to automatically enjoy efficiency gains by plugging a computer in the

\footnotetext{
${ }^{1}$ Faruqui et al. (2003).

${ }^{2}$ The Economic Report of the President, for example notes that "The 1995-2001 acceleration [in US productivity] may be plausibly accounted for by a pickup in capital services per hour worked and by increases in organizational capital, the investments businesses make to reorganize and restructure themselves, in this instance, in response to newly installed information technology." (February 2006, p. 26)
} 
socket. Rather, it is the organizational redesign which enables them to take advantage of the computing power offered by these machines that results in increased productivity.

This paper explores this basic idea by exploring the productivity gains associated with computer use and organizational redesign. It does so from a microperspective, using a rich nationally representative, longitudinal, linked workerworkplace dataset. Our methodology involves estimating a Cobb-Douglas function, augmented to account for technology use and organizational design. We use our panel data structure to correct for unobserved workplace heterogeneity using workplace fixed effects.

We find that the returns associated with computer use are large: a computer user is, on average, $37 \%$ more productive than a non-user. This rises to $47 \%$ if one accounts for potential complementarities between organizational redesign and computer use.

If complementary organizational redesign does indeed hold the key to understanding sustained productivity growth, our data suggest that the devil is in the detail. We observe no productivity effects of organizational redesign, either in isolation or in conjunction with computer use, in our aggregate data. The action is at the industry-level where organizational redesign can be either a complement or a substitute in production, and displays large inter-industry variation in terms of productivity impact.

The paper proceeds as follows. We review the literature in section 2. Section 3 provides a conceptual framework and section 4 presents our data. In section 5 , we lay out our empirical strategy. Results are presented in section 6 , and section 7 concludes. 


\section{Related Literature}

Despite a sizeable case study literature documenting complementarities between IT and organizational design, only recently has the issue been examined using survey data. ${ }^{3}$ In a seminal paper, Bresnahan, Brynjolfsson, and Hitt (2002) explore the implications of complementarities between IT, workplace reorganization, and new products and services for the relative demand for skilled labor and, more peripherally, productivity. This paper is motivated largely by Bresnahan, Brynjolfsson, and Hitt (2002) and contains many complementary results. It is, however, distinct on a number of counts. First, our focus is on productivity rather than labor demand. Second, our data permit us to examine a much larger variety organizational designs for a substantially larger number of observations; our sample is representative of the economy as a whole. ${ }^{4}$ Third, because we have access to data regarding organizational redesign and not just extant workplace practices, we are better equipped to examine the extent to which firms which adjust their organizational design in the wake of computerization realize higher productivity.

This paper also speaks to two other strands of literature: one on the effect of IT on productivity and the other on the effect of organizational design on productivity. The former is based almost exclusively on data aggregated at the macroeconomic, industry, or firm level. ${ }^{5}$ This has the drawback of concealing heterogeneity within the firm. In this paper, we study the impact of IT use on workplace productivity.

The latter - the impact of organizational design on productivity - has a long

\footnotetext{
${ }^{3}$ This is an oft lamented failure in the literature. See Brynjolfsson and Hitt (2000) for an excellent review. There is also a large sociology literature on the impact of IT on organizational design, ably surveyed in Burris (1998).

${ }^{4}$ Bresnahan, Brynjolfsson, and Hitt (2002) main estimates pertain to 250 firms. Ours pertain to 6,842 workplaces.

${ }^{5}$ Brynjolfsson and Hitt (1995), Brynjolfsson and Hitt (2003), and Stiroh (2004) survey the evidence.
} 
tradition. Some of the earliest work in this area took the form of case studies. ${ }^{6}$ An alternative approach has exploited changes in organizational structure within firms. ${ }^{7}$ Yet another approach has been to conduct intra-industry studies of the effect of workplace practices on industry-specific measures of performance. ${ }^{8}$ These studies typically find that innovative workplace practices result in higher productivity.

These approaches have the attractive quality of being rich in detail, thereby permitting an intricate understanding of the channels through which innovative workplace practices affect productivity. This level of detail is possible since the studies in question focus on particular companies, firms, or industries, but comes at a price, which is that one cannot make any generalizations to the broader economy on the basis of their results.

Some headway has been made in overcoming this limitation by analyzing data on a more representative sample of firms. But these studies typically use cross-sectional data (sometimes complemented by a longitudinal component which typically does not include business practices) with low response rates, and measures of organizational design aggregated at the firm or business-line level. ${ }^{9}$ These, in turn, make it difficult to correct for firm unobserved heterogeneity, compromises representativeness, and makes it difficult to interpret results since workplace practices often vary across establishments (and not only firms.)

In this respect, recent work by Black and Lynch (2004) and Black and Lynch

\footnotetext{
${ }^{6}$ The classic study here on the NUMMI auto assembly plant in Fremont, California (Krafcik (1988) and Wilms (1995)) was followed by case studies of firms in other industries such an office machine company (Cutcher-Gershenfeld (1991)), paper manufacturing (Ichniowski (1992)) and apparel manufacturing (Berg, Appelbaum, Bailey, and Kalleberg (1996).)

${ }^{7}$ This literature typically concentrates on the effect of incentive pay on firm or worker performance, and includes work by Lazear (2000), Knez and Simester (2001), and Hamilton, Nickerson, and Owan (2003).

${ }^{8}$ Papers taking this tack include Bailey (1993), Arthur (1994), Kelley (1994), Kelley (1996), Dunlop and Weil (1996) and Ichniowski, Shaw, and Prennushi (1997). More recently, Ann Bartel and Shaw (2007) have examined the presence of complementarities between IT and plantlevel production mechanisms in the machine-valve industry.

${ }^{9}$ Huselid (1995), Greenan and Guellec (1997), Huselid and Becker (1996), Caroli and Reenen (2001) and Kato and Morishima (2002).
} 
(2001) is ground breaking since it exploits establishment level, partially panel, data containing detailed questions on workplace practices. Nevertheless, the cross-sectional nature of the data in their 2001 paper and the small panel in their subsequent paper brings us full circle to the problems of unobserved heterogeneity and representativeness, respectively, alluded to earlier. Moreover, although they examine the effect of computer use on productivity, they do not explicitly explore the presence of interactions between computer use and workplace practices in their empirical specifications.

In this paper we use longitudinal, establishment-level panel data, the Canadian Workplace Employee Survey (WES) 1999-2004. WES is large (our final panel comprises 26,006 observations corresponding to 6,842 workplaces), nationally representative, and has detailed questions on organizational redesign, computer use, as well as complementary hardware and software adoption and investment. These features allow us to explore the effect of organizational redesign and computer use on an objective measure of productivity in enormous detail, while correcting for unobservability and producing results which are more representative of the economy as a whole and industries therein.

\section{Conceptual Preliminaries}

Computers have been described as a general purpose technology - an enabling technology whose value added to a firm derives from innovative uses (Bresnahan and Trajtenberg (1995)), and innovative uses typically require organizational redesign. To illustrate the complementarities between work organization and computer use, consider the case study of "Aircraft", described in Kling (1994). In 1988 the Aircraft engineers work group convinced management to procure them MACs, whose graphics capabilities would enhance the quality of their designs. Management agreed. As a result, the company's engineers increased 
the range and scope of problems in which they were involved, gained greater autonomy in decision making, and no longer had to rely on other workgroups in order to complete their project documents. Gains from computerization in this context resulted from a combination of IT-enabled graphics quality, and decentralization as well as reengineering.

More generally, computer-based IT can increase value added in two ways. First, it can directly increase the productivity of workers who use them (as in the case of higher quality graphic design in the example above.) Second, to the extent that one of the main things IT does is increase the potential information available within the firm, it can reduce the costs of communication, coordination, and information processing (Brynjolfsson and Hitt (2000)). The extent to which firms benefit from the second depends on whether the "right" organizational structures are in place.

In this paper, we consider the extent to which computer use at the workplace - measured by the proportion of workers using a personal computer on the job is associated with increased productivity when accompanied by organizational redesign. In particular, we consider 8 types of organizational redesign which can be classified into 3 broad areas.

The first area relates to changes in business processes. This includes greater integration among different functional units, reengineering of business processes, and total quality management (TQM). The second, closely related to the first, is changes in delegation of decision making, by which we mean an increased degree of decentralization, an increased degree of centralization, or a reduction in the number of managerial levels (delayering). The third area concerns adjustments in the workplace's dealings with other firms and includes greater reliance on external suppliers of products and services (outsourcing) and greater inter-firm collaboration in $\mathrm{R} \& \mathrm{D}$, production or marketing. 
Whether or not IT and organizational redesign are complements in production remains to be seen. What is immediately evident in our data is that organizational redesign often goes hand in hand with IT use. This can be seen in table 1. Column 2 (3) describes the proportion of workplaces, which instituted the workplace redesign indicated in column 1 and had a greater (lower) than industry-average proportion of computer users, and column 4 indicates the difference between the proportions in column 2 and 3. As the last column indicates, workplaces which recently engaged in organizational redesign are also substantially more likely to have above-average computer use.

We turn now to what the literature says about the presence or absence of complementarities between the organizational redesign and IT use.

\subsection{Business processes}

References to integration, reengineering and TQM, though favourites of the business community, find little by way of reference in the economics literature. Generically, they relate to the interaction or allocation of work between different parties, and management style in the business process.

Integration refers to increased communication and coordination among different functional units. Reengineering is in some sense, a more radical version of integration. The main proponents of reengineering, Michael Hammer and James Champy, argued that instead of organizing a firm into functional units, such as production, research, accounting and marketing, the firm should be reengineered into a series of processes governed by a team which is responsible for all the functions in the process (Hammer and Champy (1993)). TQM, wildly popularized in the early 1990s by such management gurus as Joseph Juran and Philip Crosby, is a somewhat amorphous concept, described as an "integrated management philosophy" geared towards improving product quality 
and customer satisfaction. ${ }^{10}$

By reducing the costs of communication and coordination, especially through the use of computer-aided design and management systems, computers greatly facilitate, and therefore increase the profitability associated with, the integration of functional units. This is even more true of reengineering - a concept which originated precisely in response to the possibilities afforded by new technologies. This is reflected in one of Michael Hammer's manifestos in which he declares, "Instead of embedding outdated processes in silicon and software, we should obliterate them and start over. We should " reengineer" our businesses: use the power of modern information technology to radically redesign our business processes in order to achieve dramatic improvements in their performance." (Hammer (1990), p. 105.)

If integration and reengineering are well-acknowledged complements to computer use, this is less obvious of TQM, given the breath and variety of its constituent elements. On the one hand, the value added of such things as process improvement and measurement are likely to be enhanced by computer use. But the same need not be said for such factors as "committed leadership" or "employee empowerment", which may well be compromised by computer use.

\subsection{Delegation of decision-making authority}

Of the three areas presented above, the second - the delegation of decisionmaking authority within the firm - has received the most intense scrutiny from economists. The theoretical literature has typically taken one of two tacks. The first argues that the presence of communication or information processing

\footnotetext{
${ }^{10}$ See Crosby (1984) and Juran (1992). Although different proponents place different emphases Powell (1995), in a survey of the literature maintains that TQM comprises 12 factors: committed leadership, adoption and communication of TQM through mission statements, closer customer relationships, closer supplier relationships, benchmarking, increased training, open organiztion, employee empowerment, zero-defects mentality, flexible manufacturing, process improvement and measurement.
} 
costs typically favour decentralization, to the extent that these structures better exploit local information and avoid information transmission leakages. ${ }^{11}$ The second approach focuses on incentive problems, in which the decision to decentralize decision making involves a trade-off between agency problems on the one hand, and the benefits associated with the informational advantage of agents on the other. ${ }^{12}$

To the extent that computers lower communication and information processing costs, the first strand of literature would suggest that increased computer use would increase the relative profitability of centralized decision making. To the extent that IT also improves central management's ability to monitor agents, the loss-of-control literature points to the increased relative profitability of decentralization. The net effect of computer use on the value of centralization versus decentralization is therefore ambiguous.

The effect of increased IT use on the number of managerial levels is less ambiguous. ${ }^{13}$ Firms which invest in computing technology are likely to process more data and thereby increase their profitability by reducing delayering. ${ }^{14}$ Similarly, to the extent that IT facilitates communication, and faster communication reduces coordination problems, thereby alleviating loss-of-control over layers of middle management, IT use reduces profitability associated with delayering. ${ }^{15}$

\footnotetext{
${ }^{11}$ See, for example, Bolton and Dewatripont (1994) and Radner (1993).

${ }^{12}$ See, for example, Aghion and Tirole (1997) and Acemoglu, Aghion, Lelarge, Reenen, and Zilibotti (2007). Mookherjee (2006) provides an excellent overview.

${ }^{13}$ The literature on IT and heirarchies is thin and we are grateful to Roy Radner and Kieron Meagher for invaluable input here.

${ }^{14}$ See Cukrowski and Baniak (1999) for a model of the information-processing role of IT in heirarchies.

${ }^{15}$ See and Meagher (2003).
} 


\subsection{Inter-firm interaction}

Increased outsourcing to external suppliers of products and services, and greater inter-firm collaboration in R\&D, production or marketing, and collaboration involves at least two things. The first is the ability to find an appropriate partner, and the second is being able to customize and coordinate the joint endeavour. ${ }^{16}$ In reducing the costs of communication and coordination, computer-based IT is thought to increase the productivity associated with both of oursourcing and inter-firm collaboration.

\section{Data}

Our data come from the Workplace and Employee Survey (WES) conducted by Statistics Canada. ${ }^{17}$ WES has been conducted annually since 1999 and we use all 6 years of available data (1999-2004). Our final sample comprises 26, 006 observations over 6,842 workplaces. The original WES survey contains 37, 073 observations. The discrepancy between the original and our estimation sample is mainly due to the fact that we drop non-profit-establishments $(4,593$ observations) and establishments for which no employees were sampled $(4,803$ observations). We also drop also observations with negative value added $(1,913$ observations).

The survey is both longitudinal and linked in that it documents the characteristics of workers and workplaces over time. ${ }^{18}$ The target population for the workplace component of the survey is defined as the collection of all Canadian establishments who paid employees in March of the year of the survey. The sample comes from the "Business Register" of Statistics Canada, which

\footnotetext{
${ }^{16}$ See Grossman and Helpman (2005) for a formal model.

${ }^{17}$ This is a restricted-access data set available in Statistics Canada Research Data Centers (RDC).

${ }^{18}$ Abowd and Kramarz (1999) classify WES as a survey in which both the sample of workplaces and the sample of workers are cross-sectionally representative of the target population.
} 
contains information on every business operating in Canada. The survey is therefore nationally representative of Canadian businesses, except for those located in Yukon, the Northwest Territories and Nunavut and firms operating in fisheries, agriculture and cattle farming. For the employee component, the target population is the collection of all employees working, or on paid leave, in the workplace target population. Response rates for each cross-section are over 75 per cent.

The initial 1999 sample is followed over time and is supplemented at twoyear intervals with a sample of births selected from units added to the Business Register since the last survey occasion. In the case of total non-response, respondents are withdrawn entirely from the survey and sampling weights are recalculated in order to preserve representativeness of the sample. In order to control for the design effect in our estimations, we weighted our analysis with the final sampling weights for workplaces as recommended by Statistics Canada.

In 1999, workplace data were collected in person; subsequent workplace surveys were conducted by means of computer assisted telephone interviews. For the employee component, telephone interviews were conducted with individuals who had agreed to participate in the survey by filling out and posting an employee participation form.

We have a relatively precise measure of workplace productivity (our dependent variable) in value added, defined as gross operating revenue minus expenses on materials, training and non-wage benefits. Labor is measured through the number of employees in the workplace. Our measure of capital stock is somewhat more problematic. As with most firm-level data, capital stocks for each firm are not available in our data. We therefore proxy the capital stock by taking the stock of the capital of the industry where the workplace evolved (at the three-digits for the manufacturing sector and two-digits otherwise) divided 
by the number of workplace in that particular industry (see Dostie and Pelletier (2007) and Turcotte and Rennison (2004)).

Our main measure of workplace IT use is the proportion of employees using computers (CPU) as part of their normal duties, where the survey specifically defines computers as "a micro computer, personal computer, minicomputer, mainframe computer or laptop that can be programmed to perform a variety of operations". Table 2 presents summary statistics for our sample, where the average is taken across workplaces. It indicates that the average workplace level proportion of computer users in this sample is 52 per cent. Although there is considerable inter-workplace variation in computer use, this variable does vary substantially over time within any given workplace. We also control for workforce characteristics such as union concentration, the proportion of managers and workers with at least a university degree. The workplace averages for these variables is $5 \%, 20 \%$ and $12 \%$, respectively.

In addition to computer use, we control for new technology adoption and new technology investment. The former comprises 3 separate dummy variables which take on value 1 if, respectively, between April of the previous year and March-end of the survey year a workplace implemented (i) a major new software application and/or hardware installation (Soft/Hard); (ii) computer-controlled or computer-assisted technology (CAD); and (iii) other major technologies or machinery. The latter comprises Canadian dollar-amounts for each of these three IT categories.

WES provides a rich set of measures of organizational redesign. The survey asks the following question: "Has your workplace experienced any of the following forms of organizational change between April 1 [of the previous year] and March 31 [of the current year]", following which firms are asked to respond "yes" or "no" to the 8 types of organizational redesign described in the previous 
section: (i) greater integration, (ii) greater centralization, (iii) greater decentralization, (iv) reengineering, (v) delayering, (vi) implementation of TQM, (vii) increased outsourcing, and (viii) increased inter-firm collaboration.

As table 3 indicates, over the sample period roughly a tenth of all workplaces experienced recent changes in business processes in the form of increased integration, reengineering and TQM. Increased centralization was the most common change in delegation of decision-making authority, at 6 per cent over the 6 year of observation, compared to the $2-3$ per cent of workplaces which experienced more decentralization and delayering. And $6-7$ per cent of firms recently experienced increased interaction with outside firms.

In addition to the variables mentioned above, each of our regressions includes controls for region and time dummies and, in our full sample, also two-digit industry.

\section{Empirical Strategy}

We estimate a workplace-level Cobb-Douglas production function with longitudinal data that is augmented by measures of organizational design and information technology:

$$
y_{j t}=\beta_{k} k_{j t}+\beta_{l} l_{j t}+\delta Z_{j t}+\phi X_{j t}+\gamma_{t}+\epsilon_{j t}
$$

where $j$ represents workplaces and $t$ time, $y$ is the logarithm of the firm's valueadded; $l$ is the logarithm of the freely variable input labor, and $k$ is the logarithm of the state variable capital. $Z_{j t}$ is a vector comprising the proportion of workers using a computer $\left(C_{j t}\right)$, dummy variables denoting whether or not a workplace instituted organizational redesign $\left(R_{j t}\right)$, and interaction terms between IT measures and organizational redesign $(C R) . X_{j t}$ is a vector of additional control 
variables. In all specifications, it includes workforce characteristics such as the proportion of workers covered by a collective bargaining agreement, the proportion of college graduates, the proportion of managers, and regional dummies; in our full sample, it contains controls for industry; and in some specifications it also includes controls for the investment in or adoption of complementary hardand software. $\gamma_{t}$ are time-varying intercepts and $\epsilon$ is the error term.

When $\beta_{l}$ is close to 1 , the coefficient on the proportion of workers using a computer is interpreted as the percentage productivity differential between computer users and non users. ${ }^{19}$ It is expected to be positive if employees using a computer are more productive. Coefficients on organizational redesign tell us whether those workplaces that implement changes in organizational design are also more productive. Finally, interactions between the two components capture possible complementarities between organizational redesign and computer usage. A positive coefficient indicates that a certain practice may be complementary to broad-based computer use at the workplace.

Of course, a significant coefficient is not necessarily indicative of the existence of complementarities (or substitutability) between computer use and organizational design. In particular, if there something unobserved to the econometrician

\footnotetext{
${ }^{19}$ To see this, one needs to interpret $l$ in equation (1) as the number of effective labour units that depends on the number of computer users $l^{u}$ and the number of non users $l^{n u}$

$$
l_{j t}=\lambda_{u} l_{j t}^{u}+\lambda_{n u} l_{j t}^{n u}=\lambda_{n u} l_{j t}^{a}+\left(\lambda_{u}-\lambda_{n u}\right) l_{j t}^{u}
$$

where $l^{a}$ is the actual total number of employees. $\lambda_{u}$ (and $\lambda_{n u}$ ) are load factors converting the number of employees who use (and who not use) computers into effective labor units. Equation (2) can be rewritten as

$$
\ln l_{j t}=\ln \lambda_{n u}+\ln l_{j t}^{a}+\ln \left(1+\left(\frac{\lambda_{u}}{\lambda_{n u}}-1\right) C_{j t}\right) .
$$

Substituting equation (3) in (1), we obtain

$$
y_{j t} \simeq \beta_{k} k_{j t}+\beta_{l} l_{j t}+\beta_{l} \kappa C_{j t}+\delta Z_{j t}^{*}+\phi X_{j t}+\gamma_{t}+\epsilon_{j t}
$$

where $Z_{j t}^{*}=Z_{j t}$ as defined before minus variables representing the proportion of computer users and interactions with $R$, and $\kappa=\left(\frac{\lambda_{u}}{\lambda_{n u}}-1\right)$ is one parameter of interest and is interpreted as the relative productivity of an employee who use a computer compared to an employee who does not. 
which is correlated with both organizational design, computer use, and productivity, then the observed correlation between the them may be spurious.

The problem can be seen by disaggregating the error term in equation 1 as follows:

$$
y_{j t}=\beta_{k} k_{j t}+\beta_{l} l_{j t}+\delta Z_{j t}+\phi X_{j t}+\gamma_{t}+u_{j}+\nu_{j t}
$$

where $u_{j}$ is the unobserved (time-invariant) workplace effect. We estimate equation (1) using pooled OLS and equation (5) using fixed effects (FE). ${ }^{20}$

\section{Results}

\subsection{Full sample}

Table 4 describes our pooled OLS estimates of equation for our augmented Cobb-Douglas function in (1) using the full sample.

As the first two rows indicate, the elasticity of labor is close to 1 while that of capital is close to zero, but of the wrong sign. The former is common in short panels of this type. The latter is likely to reflect the poor quality of capital stock variable, as well as the large fraction of small workplaces (over $80 \%$ have fewer than 20 employees) and service sector workplaces in our sample. The coefficient estimates for capital estimates are unfortunate and we would have liked to have a better measure of capital stock. However, we are less troubled by this than we might otherwise be for at least two reasons. First, the focus of this paper is on organizational redesign and computer use and our results are qualitatively robust to the exclusion of capital and labor inputs in our production function

\footnotetext{
${ }^{20}$ We also extensively explored, but do not report, a third alternative explanation for observed correlation, namely the possibility that that a firm may be subject to exogenous shocks (in, say, demand or efficiency advantages) which affects both the choice of inputs as well as productivity; this is the so called simultaneity problem in production function estimation (Griliches and Mairesse (1998)). We used a GMM approach suggested by Blundell and Bond (2000). However, while the results were qualitatively similar, they were also very imprecise, probably because lagged values of potentially endogenous explanatory variables acted as weak instruments.
} 
estimation. Second, as can be seen in tables 5,8 , and 9 , this elasticity of capital is insignificant in our fixed effects estimates for our sample, and of a reasonable positive magnitude (where significant) in our industry-disaggregated results.

Column 1 does not account for organizational redesign. The point estimate in row 3 of this column indicates that a computer user is roughly $38 \%$ more productive than a non user (since the coefficient on labor input is close to unity).

Including dummies for organizational redesign - integration, re-engineering, TQM, centralization, decentralization, delayering, outsourcing and collaboration - in column 2 leaves this estimate unchanged: the point estimate drops only slightly from 0.376 to 0.367 and this difference is not statistically significant. Column 3 allows for potential complementarities between organizational redesign and computer use by adding 8 interaction terms between our measures of organizational redesign and computer use. Since both hardware and software are presumably positively correlated with PC availability, organizational redesign, and productivity, failure to control for these complementary inputs may be responsible for an upward bias in our estimates. We address this in columns 4 and 5 , by correcting for the use of complementary hard- and software and investments therein, respectively.

The estimated returns associated with computer use increase by 10 percentage points (columns 2 versus column 3 ) once potential complementarities are permitted, and this increase is robust to our controls for complementary hardand software in columns 4 and 5 .

Turning to the potential complementarities between computer use and organizational redesign, as summarized in table 6 the sign of the coefficients on the interaction terms are generally remarkably consistent with the theory. Moreover, the point estimates in table 4 associated with the significant interaction 
terms are sizeable. They suggest that in a workplace that further integrates functional units, a computer user is an additional 30 percent more productive than a nonuser. Moreover, the insignificant coefficient on the integration dummy variable suggests that these gains associated with integration are enjoyed only in conjunction with computer use. The negative coefficient on the delayering interaction term coupled with the positive and significant coefficient on the corresponding dummy variable suggests, by contrast, that the average workplace which delayered becomes less productive; this is because for the average workplace, where $52 \%$ of the workforce used computers over our 6 -year observation period, the negative interaction term outweighs the positive level effect. To put it differently, productivity gains upon delayering are only enjoyed among those firms with below average computer use.

Two general results in table 4 are rather remarkable. First, although an F-test for joint significance of the interaction terms cannot be rejected at the 10 percent level, only two - increased integration of functional units and delayering - are significant. Second, of these the positive sign on integration would be consistent with it being a complement, but the negative sign on delayering would suggest that it is actually a substitute for computer use.

As discussed in the previous section, one obvious explanation for these puzzling results is workplace heterogeneity. If different types of organizational redesign are pertinent to different types of workplaces, then our OLS estimates are likely to be reflecting these unobserved differences rather than any true productivity effect of redesign. ${ }^{21}$

\footnotetext{
${ }^{21}$ Another possible explanation is measurement error. Despite detailed clarification of what is intended by each of the 8 types of organizational redesign, it is conceivable that, say, decentralization was confused with delayering, or that outsourcing was not properly distinguished from collaboration. To account for this type of measurement error, we estimated the effect of aggregated categories of organizational change. The results (not shown here) suggest that accounting for potential measurement error in this manner does not change the finding that significant interactions between computer use and organizational redesign are frequently absent and of the "wrong" sign.
} 
Table 5 accounts for this unobserved heterogeneity by estimating equation (5) using workplace FE. In these, as indeed all our FE estimations, the coefficient on our computer use variable is insignificant. While this result would be consistent with the likely possibility that our OLS estimates are biased upwards due to a selection effect, it also reflects fact that there is little variation in the proportion of computer users within a given workplace over time.

With respect to the organizational redesign, the results, summarized in the last column of table 6 indicate that the signs of the coefficients are once again, largely consistent with the theory. But they also bolster our puzzling results above. We have both positive as well as negative coefficients on our interaction terms, and with the exception of a marginally significant positive interaction on the reengineering variable, not a single organizational redesign has a significant impact on productivity either in isolation or in combination with computer use. Since there is considerable variation in organizational redesign, this is unlikely to simply be an artifact of our FE estimation.

\subsection{By industry}

Although results in tables 4 and 5 correct for industry, they do not permit for industry-specific complementarities between organizational redesign and computer use. This is problematic for at least 2 reasons. The first is measurement error. Reengineering for example is likely to mean something totally different to firms in the construction industry than firms in the entertainment industry.

The second is unobserved heterogeneity. As a number of recent intraindustry and within plant studies have shown, the appropriateness of IT, organizational redesign, and the degree to which the latter facilitates productivity gains from the former, is likely to vary from industry to industry. Centralization at a petrol plant may, for example, lead to productivity improvements if only a 
handful of people with computers have control over largely automated processes, whereas centralization in an insurance firm where human-capital intensive data gathering is important is likely to be effective only if most employees have computers. Therefore, a zero aggregate impact could mask what is in fact a negative interaction (substitutability) within some industries and a positive interaction (complementarities) within others. Failure to allow for this type of measurement error and unobserved heterogeneity may account for large standard errors in our organizational redesign coefficients and interactions in tables 4 and 5 .

Table 7 summarizes IT use as well as organizational redesign by 3 -digit industrial classifications. ${ }^{22}$ These industries include natural resource extraction $(\mathrm{NAT})^{23}$; secondary product manufacturing $(\mathrm{FAB} 2)^{24}$; labor intensive tertiary manufacturing $(\mathrm{FAB} 3 \mathrm{~L})^{25}$; capital intensive tertiary manufacturing $(\mathrm{FAB} 3 \mathrm{~K})^{26}$; construction (CON); communications (COM); finance and insurance (FIN); business services $(\mathrm{BS})^{27}$; and the entertainment industry $(\mathrm{ENT})^{28}$. Our disaggregated samples are sizable: the data contain between 1200 and 2800 observations in each of these industries, corresponding to between 350 and 780 workplaces.

Table 7 indicates that both IT use as well as the choice of organizational redesign exhibit large inter-industry variation. Computer use varies from a high

\footnotetext{
${ }^{22}$ We also have data for 4 additional industries, (i) primary product manufacturing wood products, petroleum and coal, non-metallic minerals, and primary metals (ii) retail trade and consumer services (iii) real estate, rental and leasing operations (iv) and education and health services. We do not present results pertaining to them in order to avoid overly unruly tables, since they demonstrated no evidence of significant complementarities (or substitutability) between organizational redesign and computer use in the following analysis. Estimates are available upon request.

${ }^{23}$ Support Activities for Forestry, Oil and Gas Extraction, Mining (except Oil and Gas), Support Activities for Mining

${ }^{24}$ chemicals, plastic and rubber, and fabricated metal products

${ }^{25}$ food, beverage and tobacco, textiles and textile products, clothing, leather, furniture, and miscellaneous

${ }^{26}$ printing, machinery, computer and electronics, electric equipment/appliance/component, and transportation equipment

${ }^{27}$ professional, scientific and technical services, management of companies, administrative and support services

${ }^{28}$ publishing, motion picture and sound, performance-related industries, museums and related institutions
} 
of $88 \%$ in financial services to a low of $30 \%$ in construction, and various types of organizational redesign are much more common in some industries than others.

Tables 8 , and 9 present productivity estimates disaggregated by industry. The OLS estimates in Table 8 suggest that the returns associated with computer are positive and, with two exceptions, significant even in those organizations which have not engaged in any organizational redesign . These returns also demonstrate a great deal of inter-industry variation.

At the high end, computer users in business services, natural resources and capital-intensive tertiary manufacturing are $64 \%, 55 \%$ and $54 \%$ more productive than non-users in their respective industry. At the low end, in construction and communications, a computer user is only $23 \%$ and $24 \%$ more productive than a non-user in his respective industry. And in finance and in entertainment there is no statistically significant productivity differential between a user and a nonuser. There is, moreover, no obvious pattern in these returns. For example, low returns are observed in industries with both high proportions (eg: financial services) and low proportions (eg: construction) of computer users; and as we have just seen, there is no clear pattern of higher returns being associated with manufacturing versus service industries.

A cursory comparison of the OLS and FE coefficients in tables 8 and 9 reveals a wide difference in their magnitudes, signs, and significance, confirming the consensus in the literature that unobserved workplace heterogeneity is a source of concern. In what follows we therefore restrict our attention to a description of the FE results.

As the results in Table 9 indicate, the FE model performs extremely well, explaining 85 to 95 percent of the variation in our data. It is interesting to note that, without exception, the coefficient of the significant point estimates on the organizational redesign dummy variables and their corresponding com- 
puter use interaction coefficients are of opposite signs. This is reassuring in the sense that one would not expect a profit-oriented firm to engage in practices which hurt productivity. It also suggests that where these two inputs exhibit complementarities - i.e. the coefficient on the interaction term is positive - it is these complementarities which presumably motivate the organizational design rather than any productivity benefit associated with the organizational redesign per se. By contrast where the coefficient on the interaction is significantly negative, either organizational redesign improves productivity even in the absence of computer use or, when the organizational redesign dummy is significantly positive, any productivity benefits associated with organizational redesign are only reaped by those workplace with a relatively low proportion of computer users.

What table 9 makes amply clear is that whether, and which types of organizational redesign enhance productivity either independently or in combination with IT use varies dramatically from industry to industry. In natural resource extraction, TQM is marginally complementary to computer use. In secondary manufacturing, integration is productivity enhancing and collaboration marginally productivity reducing, with or without computer use; reengineering and centralization are associated with large complementarities; and delayering is productivity enhancing only at low proportions of computer users. There are no complementarities in tertiary labor-intensive manufacturing. In capitalintensive manufacturing, by contrast, integration is complementary to computer use, while centralization and collaboration only increases productivity with a low (or zero) proportion of users.

In construction, centralization is only productivity enhancing in workplaces with a low (or zero) proportion of users, while collaboration increases productivity independent of computer use. In communications, the returns to integration 
as well as outsourcing are only positive for a large proportion of computer users, whereas centralization has a positive association with productivity regardless of the proportion of users.

In financial services, integration is productivity enhancing at lower proportions of computer use, while in business services integration only increases productivity when combined with computer use. In business services as well as entertainment, delayering is associated with higher productivity when the proportion of computer users is sufficiently low. In the latter industry, TQM and computers are complements, while collaboration is productivity enhancing when combined with a sufficiently high proportion of computer users.

In summary, the returns to some types of organizational redesign are increasing in computer use, the returns to others are only positive when the number of computer users is sufficiently small, and whether and to what extent organizational redesign has a bearing on productivity either in combination with computer use or in isolation varies from industry to industry.

\section{Conclusion}

The first 5 years of the millennium witnessed a sustained increase in productivity despite a collapse in IT investment. It is often suggested that organizational redesign which accompanies IT use may account for this. In this paper we examined this claim from a microeconomic perspective, exploiting a nationally representative, longitudinal, establishment-level survey data spanning 1999-2004, and containing a rich set of measures pertaining to IT use and organizational redesign.

We found that returns associated with computer use are large - a computer user is on average $37 \%$ more productive than a non-user - and this rises to $47 \%$ if one controls for potential interactions between organizational redesign 
and and computer use. This lends some corroboratory micro-based evidence to the suggestion that traditional growth accounting may underestimate the returns to IT. It further suggests that even as macro data indicate a collapse in IT investment, there remain large productivity gains associated with computer use. Our data suggest that the seemingly elusive "computer revolution" is very much at hand.

At the same time, there is a great deal of inter-industry variation in the productivity gains associated with computer use, which does not follow any immediately obvious pattern. The highest returns associated with computer use are found in both manufacturing and service industries, and a high proportions of computer use may be associated with very high returns (as in the business services industry) or none at all (as in financial services.) This underscores the point that it is not computers, but what one does with them which increases productivity.

With respect to potential complementarities between computer use and organizational redesign, our aggregate data are on the whole remarkably consistent with the theory - increased integration of functional units, reengineering and decentralization exhibit complementarities with computer use while increased delayering exhibits substitutability. A comparison of our OLS and FE results also indicates that unobserved heterogeneity is a source for concern and this suggests that results based on cross-sectional data should be treated with caution.

As to the main motivation of this paper, we find that if complementary organizational redesign is, indeed, the new engine of growth, then the devil is in the detail. Our fixed effects estimates using the aggregate data suggest that not a single one of eight different types of organizational redesign has a significant bearing on productivity. ${ }^{29}$ The action in our data is at the industry level, where

\footnotetext{
${ }^{29}$ Reengineering exhibits complementarities with computer use, but only at the $10 \%$ level.
} 
many types of organizational redesign do have a bearing on productivity either independently or in conjunction with computer use.

Here we draw three lessons from our data. First, where there exist complementarities between the proportion of computer users and organizational redesign, it is these complementarities rather than any benefit associated with the organizational redesign which drive productivity gains. Second, a firm need not be highly computerized (i.e. have a high proportion of computer users) in order to benefit from organizational redesign. Delayering, for instance, is productivity enhancing precisely when there is a low proportion of users. Finally, the nature in which computer use interacts with organizational redesign varies dramatically from industry to industry, both in terms of significance and sign. For firms, this means that there is no silver bullet for leveraging technological advances through organizational redesign.

Although our data enable us to address many limitations of previous work, it is not without its own drawbacks. While we control for a variety of complementary IT inputs, the proportion of computer users is simplistic measure of IT use. It would interesting to explicitly examine the kind of work done using these computers, or examine complementarities between organizational redesign and different types of IT investment. Although our data contain a rich array of organizational redesign variables, workplace organization remains a fundamentally difficult concept to measure, let alone compare across workplaces. Finally, although our panel data structure has enabled us to deal with unobserved workplace heterogeneity, the short length of the panel did not permit us to control for unobserved productivity shocks. This is left to future research. 


\section{References}

Abowd, J. M. and F. Kramarz (1999). The analysis of labor markets using matched employer-employee data. In O. Ashenfelter and D. Card (Eds.), Handbook of Labor Economics, vol 3B, Chapter 40, pp. 2629-2710. Elsevier Science North Holland.

Acemoglu, D., P. Aghion, C. Lelarge, J. V. Reenen, and F. Zilibotti (2007). Technology, information and the decentralization of the firm. Quarterly Journal of Economics 122, 1759-1799.

Aghion, P. and J. Tirole (1997). Formal and real authority in organizations. Journal of Political Economy 105, 1-29.

Ann Bartel, C. I. and K. L. Shaw (2007). How does information technology affect productivity? plant-level comparisons of product innovation, process improvement, and worker skills. Quarterly Journal of Economics 122, $1721-1758$.

Arthur, J. B. (1994). Effects of human resource systems on manufacturing performance and turnover. Academy of Management Journal 37(3), 670687.

Bailey, T. (1993). Organizational innovation in the apparel industry. Industrial Relations 32(1), 30-48.

Berg, P., E. Appelbaum, T. Bailey, and A. Kalleberg (1996). The performance effects of modular production in the apparel industry. Industrial Relations 35(3), 356-73.

Black, S. and L. Lynch (2001). How to compete: The impact of workplace practices and information technology on productivity. The Review of Economics and Statistics 83(3), 434-445. 
Black, S. E. and L. M. Lynch (2004). What's driving the new economy: the benefits of workplace innovation. The Economic Journal 114, F97-F116.

Blundell, R. and S. Bond (2000). GMM estimation with persistent panel data: An application to production functions. Econometric Reviews 19(3), 321340.

Bolton, P. and M. Dewatripont (1994). The firm as a communication network. Quarterly Journal of Economics 109, 809-339.

Bresnahan, T. F., E. Brynjolfsson, and L. M. Hitt (2002). Information technology, workplace organization and the demand for skilled labor: Firm level evidence. Quarterly Journal of Economics 117(1), 339-376.

Bresnahan, T. F. and M. Trajtenberg (1995). General purpose technologies "engines of growth"? Journal of Econometrics 65, 83-108.

Brynjolfsson, E. and L. M. Hitt (1995). Information technology as a factor of production: The role of differences among firms. Economics of Innovation and New technology 3(4), 183-200.

Brynjolfsson, E. and L. M. Hitt (2000). Beyond computation: Information technology, organizational transformation and business performance. Journal of Economic Perspectives 14(4), 23-48.

Brynjolfsson, E. and L. M. Hitt (2003). Computing productivity: Firm-level evidence. Review of Economics and Statistics 85 (4), 793-808.

Brynjolfsson, E. and S. Yang (2001). Intangible assets and growth accounting: Evidence from computer investments. Technical report, Massachusetts Institute of Technology.

Burris, B. H. (1998). Computerization of the workplace. Annual Review of Sociology 24, 141-157. 
Caroli, E. and J. V. Reenen (2001). Skilled biased organizational change? evidence from a panel of british and french establishments. Quarterly Journal of Economics 116(4), 1449-92.

Crosby, P. (1984). Quality witht Tears: The Art of Hassle-Free Management. New York: Mc-Graw-Hill.

Cukrowski, J. and A. Baniak (1999). Organizational restructuring in response to changes in information-processing technology. Review of Economic Design 4(4), 295-305.

Cutcher-Gershenfeld, J. (1991). The impact on economic performance of a transformation in workplace industrial relations. Industrial and Labor Relations Review 44(2), 241-260.

Dostie, B. and M.-P. Pelletier (2007). Les rendements de la formation en entreprise. Canadian Public Policy 33(1), 21-40.

Dunlop, J. and D. Weil (1996). Diffusion and performance of modular production in the US apparel industry. Industrial Relations 35, 334-354.

Greenan, N. and D. Guellec (1997). Firm organization, technology and performance: An empirical study. Economics of Innovation and New Technology 6(4), 313-47.

Griliches, Z. and J. Mairesse (1998). Production functions: The search for identification. In S. Strom (Ed.), Econometrics and Economic Theory in the Twentieth Century: The Ragnar Frisch Centennial Symposium, pp. 169-203. Cambridge University Press.

Grossman, G. and E. Helpman (2005). Outsourcing in a global economy. Review of Economic Studies 72(1), 135-159.

Hamilton, B. H., J. A. Nickerson, and H. Owan (2003). Team incentives and worker heterogeneity: An empirical analysis of the impact of teams 
on productivity and participation. Journal of Political Economy 111(3), $465-497$.

Hammer, M. (1990). Reengineering work: Don't automate, obliterate. Harvard Business Review July-August, 105-115.

Hammer, M. and J. A. Champy (1993). Reengineering the Corporation: A Manifesto for Business Revolution. New York: Harper Business Books.

Huselid, M. A. (1995). The impact of human resource management practices on turnover, productivity, and corporate financial performance. Academy of Management Journal 38(3), 635-672.

Huselid, M. A. and B. E. Becker (1996). Methodological issues in crosssectional and panel estimates of human resource-firm performance link. Industrial Relations 35(3), 400-422.

Ichniowski, C. (1992). Human resource practices and productive labor management relations. In D. Lewin, O. Mitchell, and P. Sherer (Eds.), Research Frontiers in Industrial Relations and Human Resources, pp. 239271. IRRA, Madison, Wisconsin.

Ichniowski, C., K. Shaw, and G. Prennushi (1997). The effects of human resource management practices on productivity: A study of steel finishing lines. American Economic Review 87(3), 291-313.

Jorgensen, D., M. S. Ho, and K. J. Stiroh (2006). Potential growth of the u.s. economy: Will the productivity resurgence continue? Business Economics 41(1), 7-16.

Jorgensen, D. and K. J. Stiroh (2000). Raising the speed limit: Us economic growth in the information age. Brookings Papers on Economic Activity $2000(1), 125-135$.

Juran, J. (1992). Juran on quality by Design. New York: Free Press. 
Kato, T. and M. Morishima (2002). The productivity effects of participatory employment practices: Evidence from new japanese panel data. Industrial Relations 4(4), 487-520.

Kelley, M. (1994). Information technology and productivity: The elusive connection. Management Science 40, 1406-25.

Kelley, M. (1996). Participative bureaucracy and productivity in the machined products sector. Industrial Relations 35, 374-99.

Kling, R. (1994). Technology, ideology and social transformation: The case of computerization and work organization. Revue International de Sociologie 2(3), 28-56.

Knez, M. and D. Simester (2001). Firm-wide incentives and mutual monitoring at continental airlines. Journal of Labor Economics 19(4), 743-72.

Krafcik, J. (1988). A triumph of the lean production system. Sloan Management Review 30, 41-52.

Lazear, E. (2000). Performance pay and productivity. American Economic Review 90(5), 1346-361.

Meagher, K. (2003). Generalizing incentives and loss of control in an optimal hierarchy: The role of information technology. Economics Letters 78(2), $273-280$.

Mookherjee, D. (2006). Decentralization, hierarchies, and incentives: A mechanism design perspective. Journal of Economic Literature 44 (2), 367-390.

Oliner, S. and D. Sichel (2000). The resurgence of growth in the late 1990s: Is information technology the story? Journal of Economic Perspectives $14(1), 3-22$.

Powell, T. C. (1995). Total quality management as competitive advantage: A review and empirical study. Strategic Management Journal 16, 15-37. 
Radner, R. (1993). The organization in decentralized information processing. Econometrica 61(5), 1109-1146.

Stiroh, K. (2004). Reassessing the role of IT in the production function: A meta-analysis. Technical report, Working Paper - Federal Reserve Bank of New York.

Turcotte, J. and L. W. Rennison (2004). Productivity and wages: Measuring the effect of human capital and technology use from linked employeremployee data. International Productivity Monitor (9), 25-36.

Wilms, W. (1995). NUMMI: An Ethnographic Study. New York: The Free Press. 
Table 1: Intensity of computer usage and organizational design

\begin{tabular}{lccc}
\hline \hline & \multicolumn{3}{c}{ \% workers using a computer* } \\
\hline Type of organizational design & Greater & Lower & Diff \\
\hline Changes in business processes & & & \\
Greater integration & 0.183 & 0.078 & 0.105 \\
Reengineering & 0.236 & 0.151 & 0.085 \\
Implemantation of TQM & 0.164 & 0.098 & 0.066 \\
Changes in delegation of decision making & & \\
Greater centralization & 0.137 & 0.045 & 0.092 \\
Greater decentralization & 0.042 & 0.018 & 0.024 \\
Delayering & 0.057 & 0.023 & 0.034 \\
Adjustments in dealings with other firms & & \\
Increased outsourcing & 0.156 & 0.089 & 0.066 \\
Increased collaboration & 0.140 & 0.059 & 0.081 \\
\hline \hline
\end{tabular}

*Relative to the industry average 


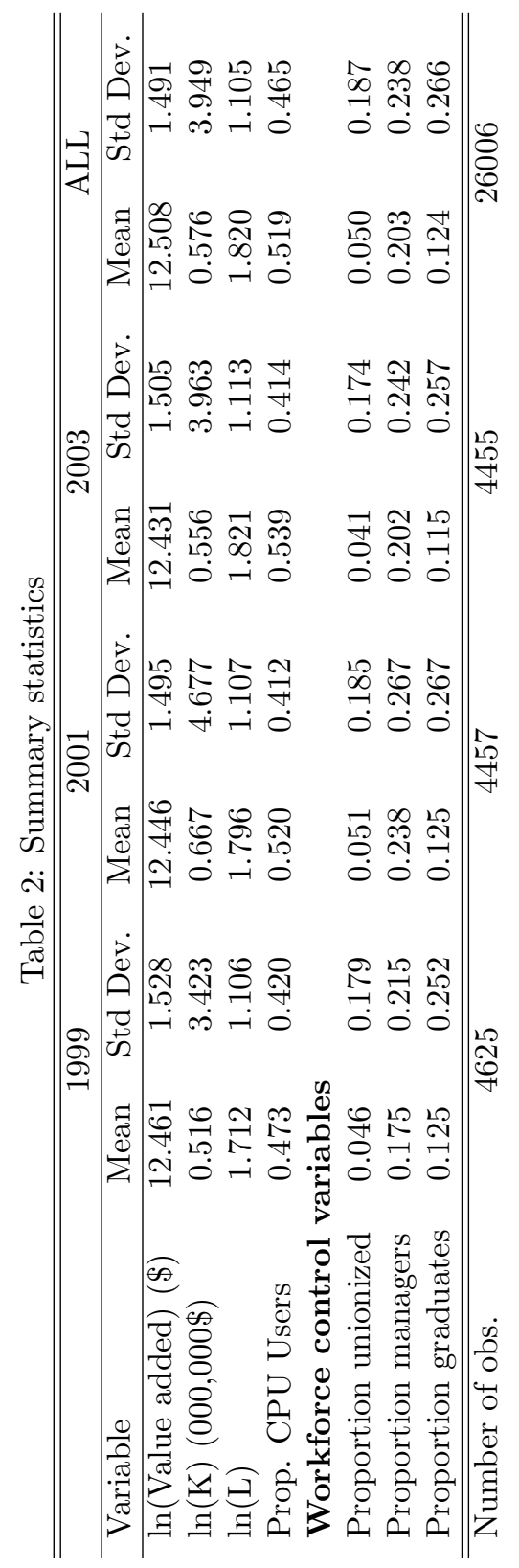


Table 3: Summary statistics

\begin{tabular}{lcccc}
\hline \hline & 1999 & 2001 & 2003 & ALL \\
Variable & Mean & Mean & Mean & Mean \\
Changes in business processes & & & & \\
Integration & 0.12 & 0.08 & 0.08 & 0.09 \\
Re-engineering & 0.19 & 0.13 & 0.11 & 0.12 \\
TQM & 0.13 & 0.08 & 0.05 & 0.08 \\
Changes in delegation & & & & \\
Centralization & 0.09 & 0.06 & 0.02 & 0.06 \\
Decentralization & 0.03 & 0.03 & 0.02 & 0.02 \\
Delayering & 0.04 & 0.02 & 0.03 & 0.03 \\
Dealings with other firms & & & & \\
Outsource & 0.13 & 0.07 & 0.05 & 0.07 \\
Collaboration & 0.10 & 0.06 & 0.04 & 0.06 \\
Industry & & & & \\
Natural Resources (NAT) & 0.02 & 0.02 & 0.01 & 0.02 \\
Primary manufacturing (FAB1) & 0.01 & 0.01 & 0.01 & 0.01 \\
Secondary manufacturing (FAB2) & 0.02 & 0.02 & 0.02 & 0.02 \\
Labour tertiary (FAB3L) & 0.03 & 0.03 & 0.03 & 0.03 \\
Capital tertiary (FAB3K) & 0.03 & 0.03 & 0.04 & 0.03 \\
Construction (CON) & 0.08 & 0.08 & 0.09 & 0.08 \\
Transport (TRA) & 0.13 & 0.11 & 0.12 & 0.12 \\
Communication (COM) & 0.01 & 0.02 & 0.01 & 0.01 \\
Retail (RET) & 0.35 & 0.34 & 0.35 & 0.35 \\
Finance and insurance (FIN) & 0.06 & 0.06 & 0.05 & 0.05 \\
Real estate (REA) & 0.04 & 0.04 & 0.04 & 0.04 \\
Business services (BS) & 0.12 & 0.14 & 0.12 & 0.12 \\
Education and health care (EH) & 0.09 & 0.09 & 0.09 & 0.09 \\
Information and culture (ENT) & 0.02 & 0.02 & 0.02 & 0.02 \\
\hline \hline Number of observations: & 4625 & 4457 & 4455 & 26006 \\
\hline
\end{tabular}


Table 4: Workplace Productivity and Computer Use - OLS Coefficient Estimates

\begin{tabular}{|c|c|c|c|c|c|}
\hline & $\overline{(1)}$ & (2) & 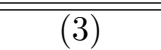 & (4) & $(5)$ \\
\hline $\ln (\mathrm{L})$ & $\begin{array}{c}0.987^{* * *} * \\
(0.012)\end{array}$ & $\begin{array}{c}0.977^{* * *} \\
(0.013)\end{array}$ & $\begin{array}{c}0.982^{* * *} \\
(0.012)\end{array}$ & $\begin{array}{c}0.981^{* * *} * \\
(0.012)\end{array}$ & $\begin{array}{c}0.982^{* * *} \\
(0.012)\end{array}$ \\
\hline $\ln (\mathrm{K})$ & $\begin{array}{c}-0.051^{* * *} \\
(0.014)\end{array}$ & $\begin{array}{c}-0.049^{* * *} \\
(0.014)\end{array}$ & $\begin{array}{c}-0.050^{* * *} \\
(0.014)\end{array}$ & $\begin{array}{c}-0.051^{* * *} \\
(0.014)\end{array}$ & $\begin{array}{c}-0.050 * * * \\
(0.014)\end{array}$ \\
\hline Prop. CPU users & $\begin{array}{c}0.376^{* * *} \\
(0.097)\end{array}$ & $\begin{array}{c}0.367^{* * *} \\
(0.095)\end{array}$ & $\begin{array}{c}0.474^{* * *} \\
(0.049)\end{array}$ & $\begin{array}{c}0.463^{* * *} \\
(0.050)\end{array}$ & $\begin{array}{c}0.473^{* * *} \\
(0.049)\end{array}$ \\
\hline \multicolumn{6}{|c|}{ Changes in business processes } \\
\hline Integration & & $\begin{array}{c}0.116^{* *} \\
(0.051)\end{array}$ & $\begin{array}{l}-0.060 \\
(0.086)\end{array}$ & $\begin{array}{c}-0.067 \\
(0.086)\end{array}$ & $\begin{array}{c}-0.060 \\
(0.086)\end{array}$ \\
\hline CPU*Integration & & & $\begin{array}{c}0.274^{* *} \\
(0.137)\end{array}$ & $\begin{array}{c}0.279^{* *} \\
(0.137)\end{array}$ & $\begin{array}{c}0.275^{* *} \\
(0.137)\end{array}$ \\
\hline Re-engineering & & $\begin{array}{c}-0.006 \\
(0.046)\end{array}$ & $\begin{array}{l}-0.088 \\
(0.079)\end{array}$ & $\begin{array}{l}-0.089 \\
(0.079)\end{array}$ & $\begin{array}{l}-0.088 \\
(0.079)\end{array}$ \\
\hline CPU*Re-engineering & & & $\begin{array}{c}0.129 \\
(0.117)\end{array}$ & $\begin{array}{c}0.126 \\
(0.117)\end{array}$ & $\begin{array}{c}0.128 \\
(0.117)\end{array}$ \\
\hline TQM & & $\begin{array}{l}-0.054 \\
(0.067)\end{array}$ & $\begin{array}{c}0.115 \\
(0.105)\end{array}$ & $\begin{array}{c}0.111 \\
(0.105)\end{array}$ & $\begin{array}{c}0.115 \\
(0.105)\end{array}$ \\
\hline $\mathrm{CPU}^{*} \mathrm{TQM}$ & & & $\begin{array}{l}-0.263 \\
(0.169)\end{array}$ & $\begin{array}{l}-0.254 \\
(0.169)\end{array}$ & $\begin{array}{l}-0.264 \\
(0.169)\end{array}$ \\
\hline \multicolumn{6}{|c|}{ Changes in delegation of decision making } \\
\hline Centralization & & $\begin{array}{c}0.197^{* * *} \\
(0.066)\end{array}$ & $\begin{array}{c}0.180 \\
(0.151)\end{array}$ & $\begin{array}{c}0.176 \\
(0.151)\end{array}$ & $\begin{array}{c}0.180 \\
(0.151)\end{array}$ \\
\hline CPU*Centralization & & & $\begin{array}{l}-0.018 \\
(0.195)\end{array}$ & $\begin{array}{l}-0.016 \\
(0.195)\end{array}$ & $\begin{array}{l}-0.019 \\
(0.194)\end{array}$ \\
\hline Decentralization & & $\begin{array}{l}-0.132 \\
(0.112)\end{array}$ & $\begin{array}{c}-0.308^{* *} \\
(0.143)\end{array}$ & $\begin{array}{c}-0.308^{* *} \\
(0.143)\end{array}$ & $\begin{array}{c}-0.309^{* *} \\
(0.143)\end{array}$ \\
\hline CPU*Decentralization & & & $\begin{array}{c}0.259 \\
(0.229)\end{array}$ & $\begin{array}{c}0.258 \\
(0.230)\end{array}$ & $\begin{array}{c}0.259 \\
(0.229)\end{array}$ \\
\hline Delayering & & $\begin{array}{c}-0.224 \\
(0.161)\end{array}$ & $\begin{array}{c}0.370^{* * * *} \\
(0.141)\end{array}$ & $\begin{array}{c}0.366^{* * *} \\
(0.141)\end{array}$ & $\begin{array}{c}0.370^{* * *} \\
(0.141)\end{array}$ \\
\hline CPU*Delayering & & & $\begin{array}{c}-0.880^{* * *} \\
(0.279)\end{array}$ & $\begin{array}{c}-0.881^{* * *} \\
(0.278)\end{array}$ & $\begin{array}{c}-0.880^{* * * *} \\
(0.279)\end{array}$ \\
\hline
\end{tabular}

Statistical significance: ${ }^{*}=10 \% ;{ }^{* *}=5 \% ;{ }^{* * *}=1 \%$

NOTE: Standard Errors in Parentheses 
Table 4: Workplace Productivity and Computer Use - OLS Coefficient Estimates (Cont'd)

\begin{tabular}{|c|c|c|c|c|c|}
\hline & $(1)$ & $(2)$ & $(3)$ & $(4)$ & $\overline{(5)}$ \\
\hline \multicolumn{6}{|c|}{ Adjustments in the workplace's dealings with other firms } \\
\hline \multirow[t]{2}{*}{ Outsource } & & 0.020 & -0.085 & -0.081 & -0.085 \\
\hline & & $(0.064)$ & $(0.103)$ & $(0.103)$ & $(0.103)$ \\
\hline \multirow[t]{2}{*}{ CPU*Outsource } & & & 0.174 & 0.162 & 0.174 \\
\hline & & & $(0.166)$ & $(0.166)$ & $(0.166)$ \\
\hline \multirow[t]{2}{*}{ Collaboration } & & $0.102 *$ & 0.086 & 0.082 & 0.085 \\
\hline & & $(0.060)$ & $(0.107)$ & $(0.107)$ & $(0.107)$ \\
\hline \multirow[t]{2}{*}{ CPU*Collaboration } & & & -0.003 & 0.003 & -0.002 \\
\hline & & & $(0.144)$ & $(0.144)$ & $(0.144)$ \\
\hline Constant & $\begin{array}{c}11.072^{* * *} \\
(0.089)\end{array}$ & $\begin{array}{c}11.068^{* * *} \\
(0.087)\end{array}$ & $\begin{array}{c}11.032^{* * *} \\
(0.082)\end{array}$ & $\begin{array}{c}11.038^{* * *} \\
(0.083)\end{array}$ & $\begin{array}{c}11.032^{* * *} \\
(0.082)\end{array}$ \\
\hline Workforce control variables & YES & YES & YES & YES & YES \\
\hline New technologies dummies & NO & NO & NO & YES & NO \\
\hline New tech. $\$$ invested & $\mathrm{NO}$ & $\mathrm{NO}$ & $\mathrm{NO}$ & NO & YES \\
\hline Industry dummies & YES & YES & YES & YES & YES \\
\hline Year dummies & YES & YES & YES & YES & YES \\
\hline Regions dummies & YES & YES & YES & YES & YES \\
\hline \# Observations & 26006 & 26006 & 26006 & 26006 & 26006 \\
\hline \# Workplaces & 6842 & 6842 & 6842 & 6842 & 6842 \\
\hline R-squared & 0.61 & 0.62 & 0.62 & 0.62 & 0.62 \\
\hline
\end{tabular}

Statistical significance: ${ }^{*}=10 \% ;{ }^{* *}=5 \% ;{ }^{* * *}=1 \%$

NOTE: Standard Errors in Parentheses 
Table 5: Workplace Productivity and Computer Use - FE Coefficient Estimates

\begin{tabular}{|c|c|c|c|c|c|}
\hline \multirow{3}{*}{$\ln (\mathrm{L})$} & $(1)$ & $(2)$ & $(3)$ & $(4)$ & (5) \\
\hline & $0.626^{* * *}$ & $0.624^{* * *}$ & $0.622^{* * *}$ & $0.620^{* * *}$ & $0.622^{* * *}$ \\
\hline & $(0.050)$ & $(0.050)$ & $(0.050)$ & $(0.050)$ & $(0.050)$ \\
\hline $\ln (\mathrm{K})$ & $\begin{array}{l}-0.043 \\
(0.039)\end{array}$ & $\begin{array}{l}-0.039 \\
(0.039)\end{array}$ & $\begin{array}{l}-0.038 \\
(0.039)\end{array}$ & $\begin{array}{l}-0.037 \\
(0.039)\end{array}$ & $\begin{array}{l}-0.038 \\
(0.039)\end{array}$ \\
\hline Prop. CPU users & $\begin{array}{l}-0.006 \\
(0.035)\end{array}$ & $\begin{array}{l}-0.006 \\
(0.034)\end{array}$ & $\begin{array}{c}0.007 \\
(0.070)\end{array}$ & $\begin{array}{c}0.003 \\
(0.070)\end{array}$ & $\begin{array}{c}0.007 \\
(0.070)\end{array}$ \\
\hline \multicolumn{6}{|c|}{ Changes in business processes } \\
\hline Integration & & $\begin{array}{l}0.082^{*} \\
(0.046)\end{array}$ & $\begin{array}{c}0.029 \\
(0.089)\end{array}$ & $\begin{array}{c}0.024 \\
(0.089)\end{array}$ & $\begin{array}{c}0.029 \\
(0.089)\end{array}$ \\
\hline \multicolumn{2}{|l|}{ CPU*Integration } & & $\begin{array}{c}0.083 \\
(0.131)\end{array}$ & $\begin{array}{c}0.086 \\
(0.131)\end{array}$ & $\begin{array}{c}0.083 \\
(0.131)\end{array}$ \\
\hline Re-engineering & & $\begin{array}{c}0.037 \\
(0.040)\end{array}$ & $\begin{array}{c}-0.073 \\
(0.075)\end{array}$ & $\begin{array}{l}-0.073 \\
(0.075)\end{array}$ & $\begin{array}{l}-0.073 \\
(0.075)\end{array}$ \\
\hline \multicolumn{2}{|l|}{ CPU*Re-engineering } & & $\begin{array}{l}0.191^{*} \\
(0.113)\end{array}$ & $\begin{array}{l}0.188^{*} \\
(0.112)\end{array}$ & $\begin{array}{l}0.191^{*} \\
(0.113)\end{array}$ \\
\hline TQM & & $\begin{array}{l}-0.035 \\
(0.053)\end{array}$ & $\begin{array}{l}-0.032 \\
(0.083)\end{array}$ & $\begin{array}{l}-0.031 \\
(0.082)\end{array}$ & $\begin{array}{l}-0.032 \\
(0.083)\end{array}$ \\
\hline \multicolumn{2}{|l|}{$\mathrm{CPU}^{*} \mathrm{TQM}$} & & $\begin{array}{l}-0.001 \\
(0.151)\end{array}$ & $\begin{array}{l}-0.004 \\
(0.150)\end{array}$ & $\begin{array}{l}-0.001 \\
(0.151)\end{array}$ \\
\hline \multicolumn{6}{|c|}{ Changes in delegation of decision making } \\
\hline Centralization & & $\begin{array}{c}-0.077 \\
(0.052)\end{array}$ & $\begin{array}{c}0.045 \\
(0.087)\end{array}$ & $\begin{array}{c}0.044 \\
(0.087)\end{array}$ & $\begin{array}{c}0.045 \\
(0.087)\end{array}$ \\
\hline \multicolumn{2}{|l|}{$\mathrm{CPU}^{*}$ Centralization } & & $\begin{array}{l}-0.193 \\
(0.122)\end{array}$ & $\begin{array}{l}-0.191 \\
(0.122)\end{array}$ & $\begin{array}{l}-0.193 \\
(0.122)\end{array}$ \\
\hline Decentralization & & $\begin{array}{l}-0.039 \\
(0.109)\end{array}$ & $\begin{array}{l}-0.064 \\
(0.167)\end{array}$ & $\begin{array}{l}-0.065 \\
(0.167)\end{array}$ & $\begin{array}{l}-0.064 \\
(0.167)\end{array}$ \\
\hline \multicolumn{2}{|l|}{ CPU*Decentralization } & & $\begin{array}{c}0.036 \\
(0.199)\end{array}$ & $\begin{array}{c}0.039 \\
(0.198)\end{array}$ & $\begin{array}{c}0.036 \\
(0.199)\end{array}$ \\
\hline \multicolumn{2}{|l|}{ Delayering } & $\begin{array}{l}-0.084 \\
(0.137)\end{array}$ & $\begin{array}{c}0.142 \\
(0.147)\end{array}$ & $\begin{array}{c}0.138 \\
(0.148)\end{array}$ & $\begin{array}{c}0.142 \\
(0.147)\end{array}$ \\
\hline \multicolumn{2}{|l|}{ CPU*Delayering } & & $\begin{array}{c}-0.336 \\
(0.210) \\
\end{array}$ & $\begin{array}{l}-0.330 \\
(0.210)\end{array}$ & $\begin{array}{c}-0.336 \\
(0.210)\end{array}$ \\
\hline
\end{tabular}

Statistical significance: ${ }^{*}=10 \% ;{ }^{* *}=5 \% ;{ }^{* * *}=1 \%$

NOTE: Standard Errors in Parentheses 
Table 5: Workplace Productivity and Computer Use - FE Coefficient Estimates (Cont'd)

\begin{tabular}{|c|c|c|c|c|c|}
\hline & (1) & $(2)$ & $(3)$ & $(4)$ & $(5)$ \\
\hline \multicolumn{6}{|c|}{ Adjustments in the workplace's dealings with other firms } \\
\hline Outsource & & $\begin{array}{c}0.001 \\
(0.046)\end{array}$ & $\begin{array}{c}0.037 \\
(0.084)\end{array}$ & $\begin{array}{c}0.035 \\
(0.084)\end{array}$ & $\begin{array}{c}0.037 \\
(0.084)\end{array}$ \\
\hline CPU*Outsource & & & $\begin{array}{l}-0.068 \\
(0.124)\end{array}$ & $\begin{array}{l}-0.066 \\
(0.123)\end{array}$ & $\begin{array}{l}-0.067 \\
(0.124)\end{array}$ \\
\hline Collaboration & & $\begin{array}{c}0.069 \\
(0.054)\end{array}$ & $\begin{array}{c}0.133 \\
(0.094)\end{array}$ & $\begin{array}{c}0.129 \\
(0.093)\end{array}$ & $\begin{array}{c}0.133 \\
(0.094)\end{array}$ \\
\hline CPU*Collaboration & & & $\begin{array}{l}-0.100 \\
(0.126)\end{array}$ & $\begin{array}{l}-0.096 \\
(0.125)\end{array}$ & $\begin{array}{l}-0.100 \\
(0.126)\end{array}$ \\
\hline Constant & $\begin{array}{c}11.953^{* * *} \\
(0.334)\end{array}$ & $\begin{array}{c}11.949^{* * *} \\
(0.333)\end{array}$ & $\begin{array}{c}11.944^{* * *} \\
(0.334)\end{array}$ & $\begin{array}{c}11.945^{* * *} \\
(0.336)\end{array}$ & $\begin{array}{c}11.944^{* * *} \\
(0.334)\end{array}$ \\
\hline Workforce control variables & YES & YES & YES & YES & YES \\
\hline New technologies dummies & NO & $\mathrm{NO}$ & $\mathrm{NO}$ & YES & NO \\
\hline New tech. $\$$ invested & NO & NO & NO & NO & YES \\
\hline Industry dummies & YES & YES & YES & YES & YES \\
\hline Year dummies & YES & YES & YES & YES & YES \\
\hline Regions dummies & YES & YES & YES & YES & YES \\
\hline \# Observations & 26006 & 26006 & 26006 & 26006 & 26006 \\
\hline \# Workplaces & 6842 & 6842 & 6842 & 6842 & 6842 \\
\hline R-squared & 0.88 & 0.88 & 0.88 & 0.88 & 0.88 \\
\hline
\end{tabular}

Statistical significance: ${ }^{*}=10 \% ;{ }^{* *}=5 \% ;{ }^{* * *}=1 \%$

NOTE: Standard Errors in Parentheses

Table 6: Summary of Complementarities: full sample

\begin{tabular}{|l|c|c|c|}
\hline \multirow{2}{*}{ ORGANIZATIONAL REDESIGN } & \multicolumn{3}{|c|}{ Complementarity } \\
\cline { 2 - 4 } & theory & OLS estimate & FE estimate \\
\hline \hline Business Processes & + & $+^{* *}$ & + \\
\hline Integration & + & + & $+^{*}$ \\
Reengineering & $+/-$ & - & - \\
TQM & $+/-$ & - & - \\
\hline Decision-Making Authority & +- & + \\
\hline Centralization & - & $-* *$ & - \\
Decentralization & \multicolumn{3}{|}{} \\
Delayering & + & + & - \\
\hline Inter-firm interaction & + & - & - \\
\hline Outsourcing & & + & \\
Collaboration in R\&D & R*
\end{tabular}

* significant at $10 \%$; ${ }^{* *}$ significant at $5 \%$; ${ }^{* * *}$ significant at $1 \%$ 


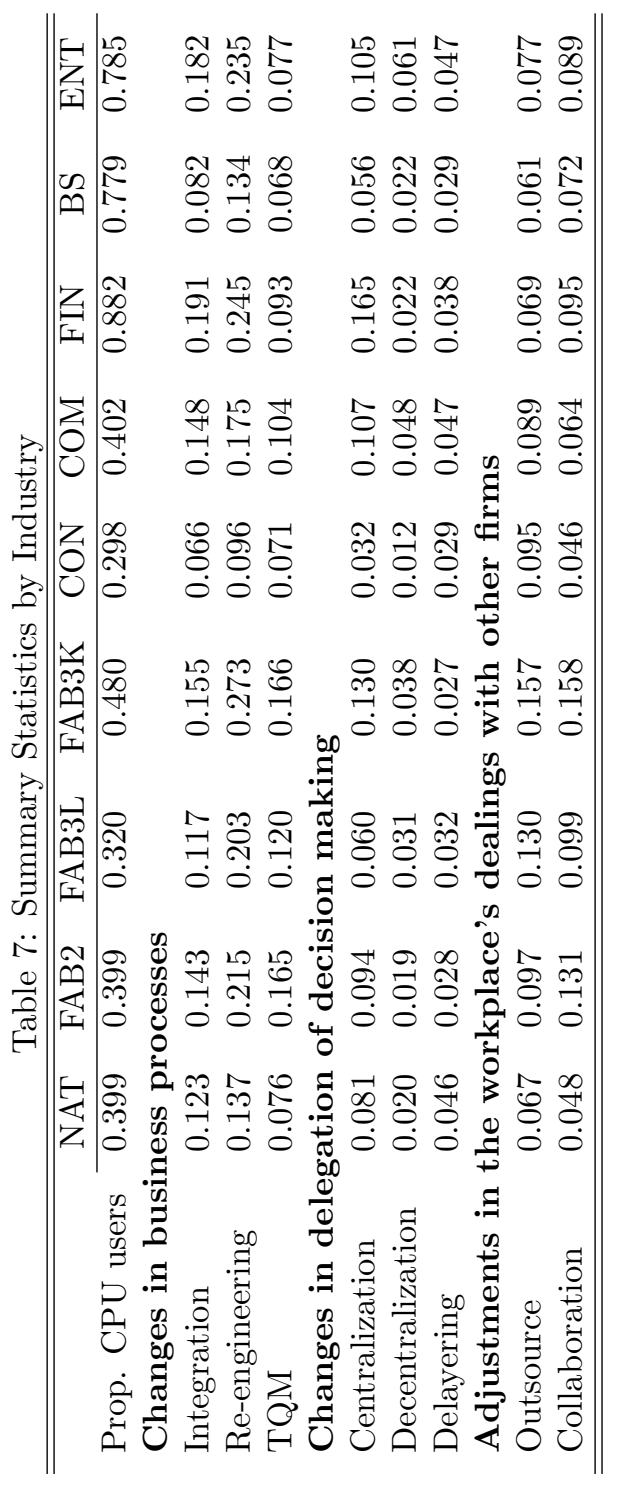




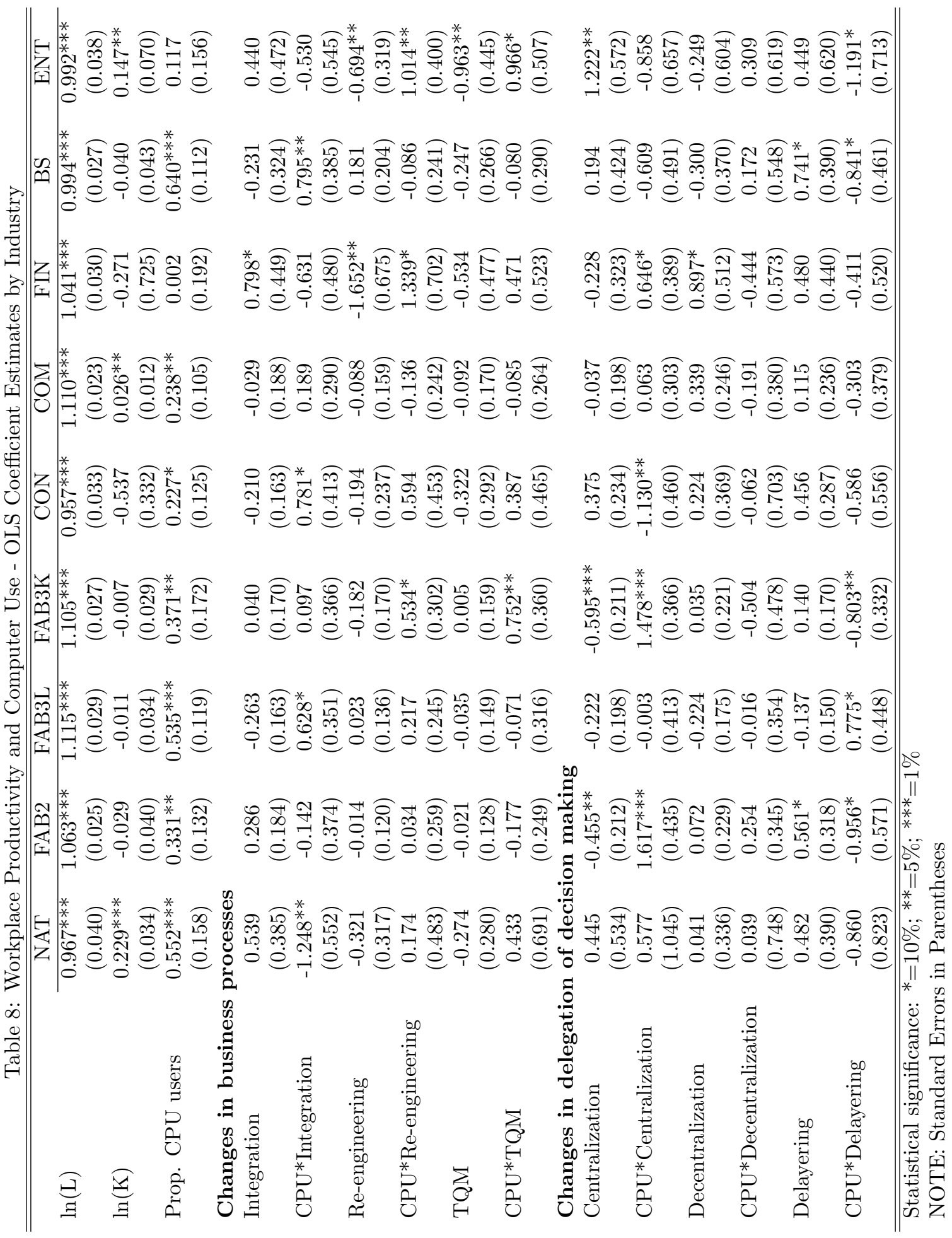




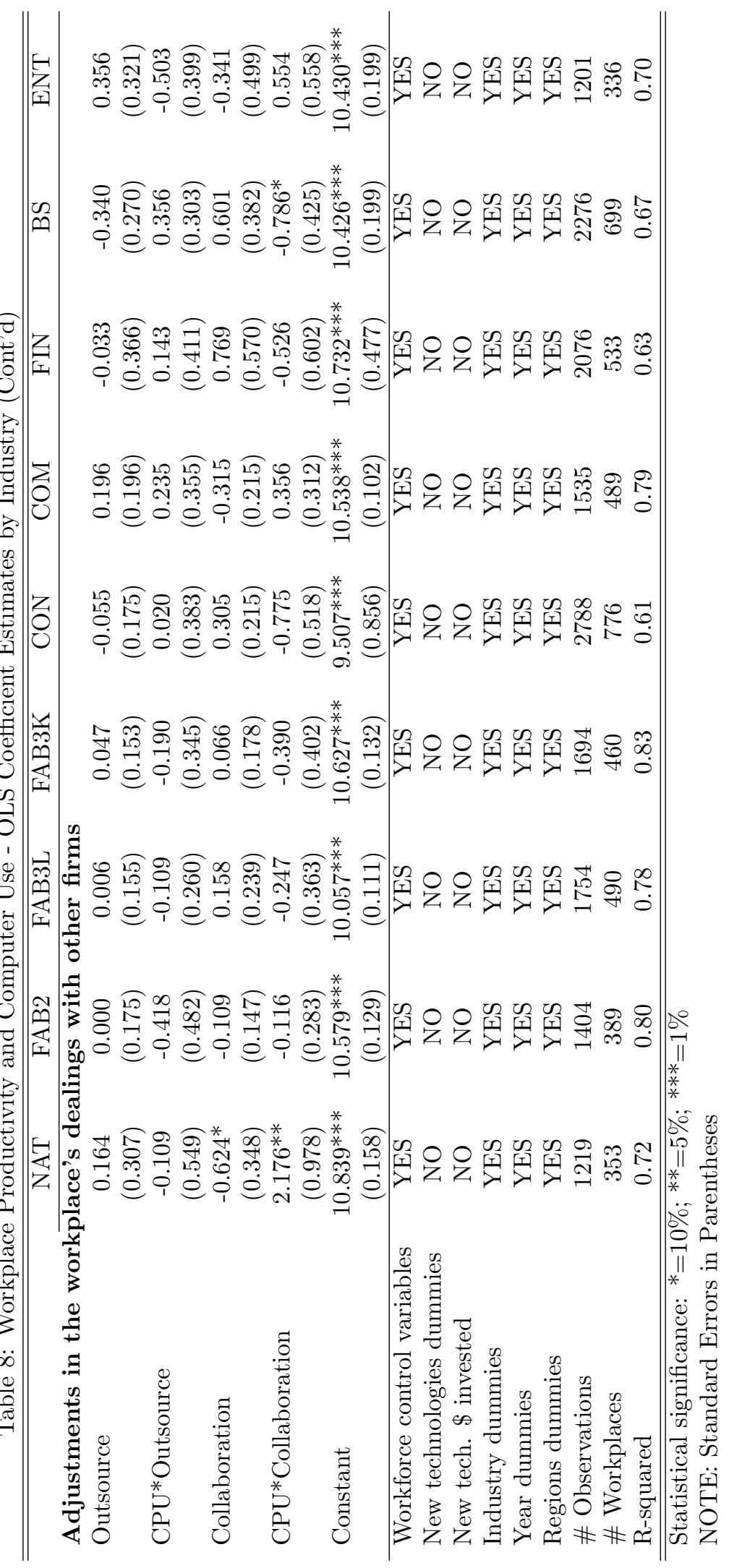




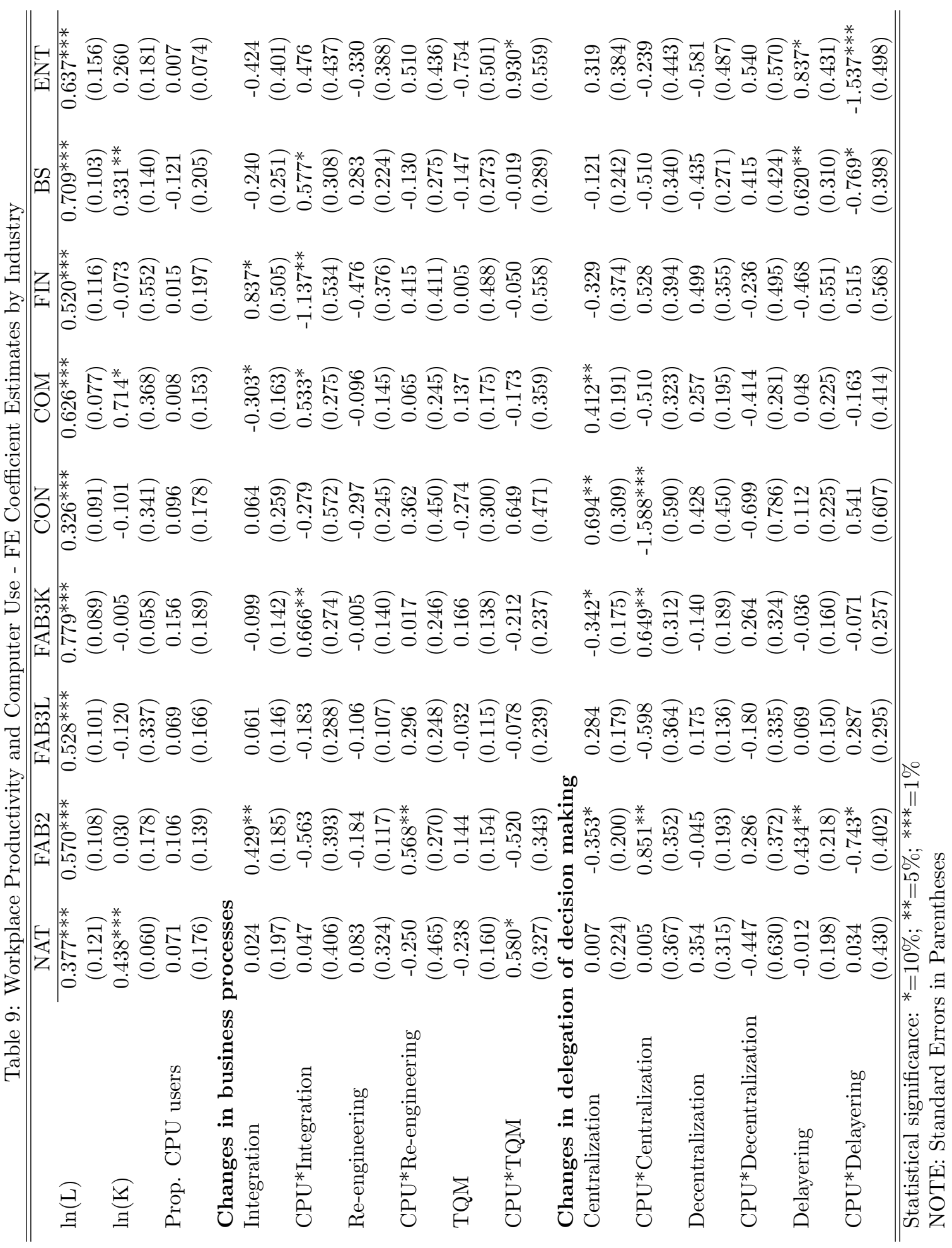




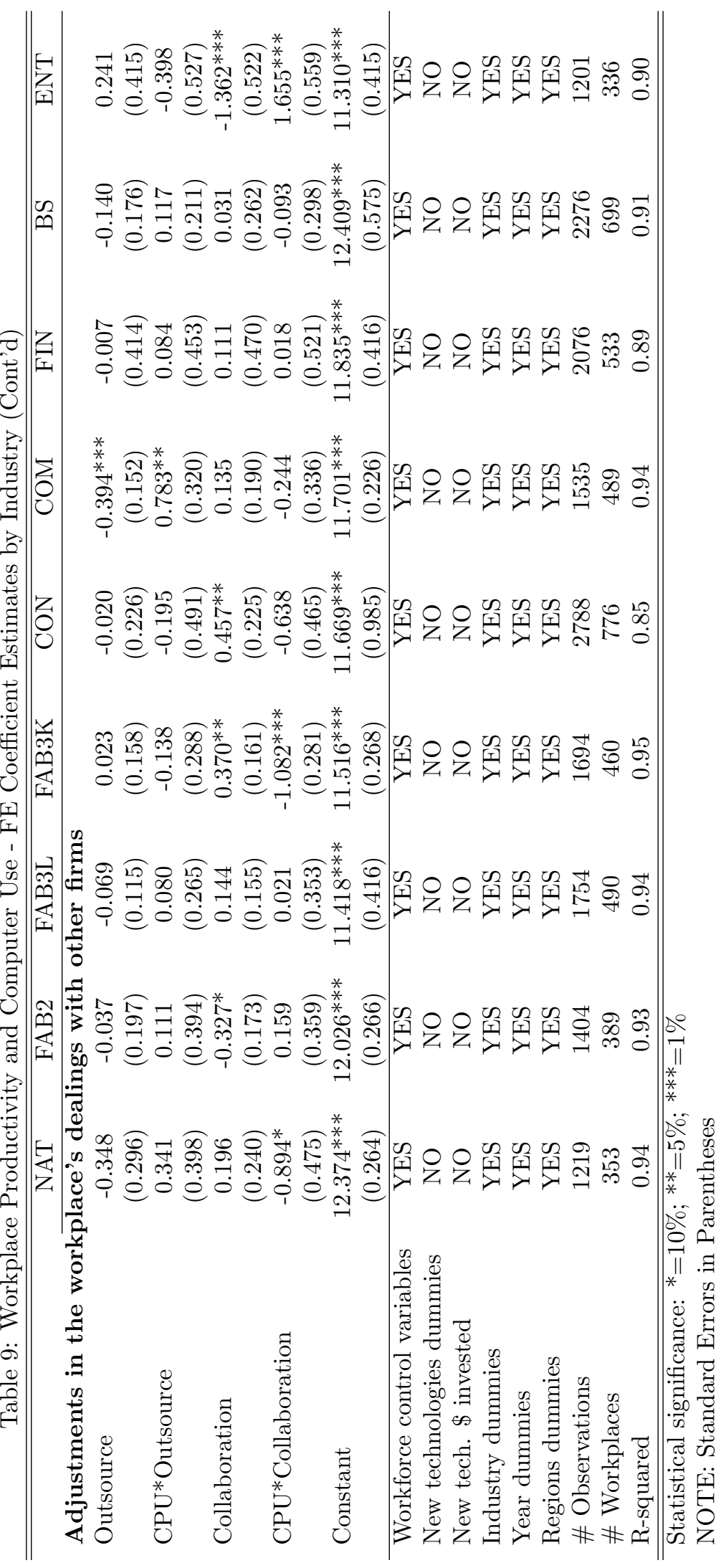

